OPEN ACCESS

Edited by:

Robbert Spaapen,

AMC-Sanquin Landsteiner

Laboratory, Netherlands

Reviewed by:

Subramaniam Malarkannan, Medical College of Wisconsin,

United States

Yi Zhang,

Temple University, United States

${ }^{*}$ Correspondence: Eun Young Choi eycii@snu.ac.kr

Specialty section:

This article was submitted to Cancer Immunity and Immunotherapy, a section of the journal

Frontiers in Immunology

Received: 20 January 2020 Accepted: 12 May 2020

Published: 10 June 2020

Citation:

Choi EY, Choi K, Nam G, Kim W and Chung M (2020) H6O: A Unique Murine Hematopoietic Cell-Restricted Minor Histocompatibility Antigen for Graft-versus-Leukemia Effect. Front. Immunol. 11:1163. doi: 10.3389/fimmu.2020.01163

\section{H60: A Unique Murine Hematopoietic Cell-Restricted Minor Histocompatibility Antigen for Graft-versus-Leukemia Effect}

\author{
Eun Young Choi ${ }^{1,2 *}$, Kyungho Choi ${ }^{1,3,4}$, Giri Nam ${ }^{1}$, Woojin $\mathrm{Kim}^{1}$ and Minho Chung ${ }^{1}$ \\ ${ }^{1}$ Department of Biomedical Sciences, Seoul National University College of Medicine, Seoul, South Korea, ${ }^{2}$ Institute of \\ Human Environment Interface Biology, Seoul National University College of Medicine, Seoul, South Korea, ${ }^{3}$ Department of \\ Biochemistry and Molecular Biology, Seoul National University College of Medicine, Seoul, South Korea, ${ }^{4}$ Cancer Research \\ Institute, Seoul National University College of Medicine, Seoul, South Korea
}

Allogeneic hematopoietic stem cell transplantation (allo-HSCT) is an important treatment for many types of hematological malignancies. Matching of donor and recipient for the major histocompatibility complex (MHC) improves the HSCT reconstitution, but donor-derived $\mathrm{T}$ cells reactive to non-MHC encoded minor histocompatibility antigens (MiHAs) can induce graft-versus-host disease (GVHD) while also being needed for graft-versus-leukemia (GVL) effects. MiHAs are allelically variant self-peptides presented conventionally on $\mathrm{MHC}$ molecules, but are alloantigenic in transplantation settings. Immunodominant MiHAs are most strongly associated with GVHD and GVL. There is need for mouse paradigms to understand these contradictory effects. $\mathrm{H} 60$ is a highly immunodominant mouse MiHA with hematopoietic cell-restricted expression. Immunodominance of $\mathrm{H} 60$ is tightly associated with its allelic nature (presence vs. absence of the transcripts), and the qualitative (TCR diversity) and quantitative (frequency) traits of the reactive $T$ cells. The identity as a hematopoietic cell-restricted antigen (HRA) of $\mathrm{H} 60$ assists the appearance of the immunodominace in allo-HSCT circumstances, and generation of GVL effects without induction of serious GVHD after adoptive T cell transfer. Also it allows the low avidity T cells to escape thymic negative selection and exert GVL effect in the periphery, which is a previously unevaluated finding related to HRAs. In this review, we describe the molecular features and immunobiology in detail through which H60 selectively exerts its potent GVL effect. We further describe how lessons learned can be extrapolated to human allo-HCST.

Keywords: H60, minor histocompatibility antigen, graft-versus-leukemia, graft-versus-host-disease, hematopoieic cell-restricted antigen

\section{INTRODUCTION}

Allogeneic hematopoietic stem cell transplantation (allo-HSCT) was originally developed as a means to reconstitute the immune system of patients with hematological malignancies after anti-tumor radio/chemotherapy (1). T cell repopulation shortly after transplantation is attributed to the expansion of mature $\mathrm{T}$ cells from the donor bone marrow (BM) inoculum, rather than de novo $\mathrm{T}$ cell regeneration (2). Ideally, these mature donor-derived 
$\mathrm{T}$ cells confer rapid protection from infection following alloHSCT, while also being cytotoxic to residual tumor cells. This latter phenomenon is referred to as the graft-versus-leukemia (GVL) effect (3). Thus, allo-HSCT is considered as an antitumor treatment modality beyond its immune reconstitution capability. Mechanistically, donor-derived mature $\mathrm{T}$ cells elicit the GVL effect via recognition of host allo-antigens expressed by hematopoietic tumor cells (4). The downside is that they can also attack normal host tissues expressing allo-antigens and induce severe systemic inflammation, multi-organ failure, and mortality, a syndrome referred to as graft-versus-host disease (GVHD) (5). Although major histocompatibility complex (MHC)-matched transplantation significantly reduces the risk of GVHD, disparity at minor histocompatibility antigens (MiHA) continues to incur risk for GVHD whose target organs include intestine, skin, and liver (5-7). Thus, a matter of great interest is to minimize GVHD, while retaining the anti-tumor response. Particularly strong MiHAs whose expression is limited to hematopoietic cells are attractive targets for accomplishing this goal.

MiHAs arise from the fraction of self-peptides presented conventionally on MHC molecules that happen to be allelically variant (8). Their antigenicity is revealed in transplantation settings because such variant peptides are perceived as foreign to a host's $\mathrm{T}$ cells. With the advances in genome wide sequencing and $\mathrm{T}$ cell-epitope identification technologies, the number of molecularly identified MiHAs has increased exponentially (9-11). Immunodominant MiHAs have attracted attention as immunotherapeutic targets for hematologic malignancies (12-14). In this review, we describe the molecular features and immunobiology of an unusually immunodominant mouse MiHA, H60, that engender its potent GVL effect.

\section{H60 AND ITS IMMUNODOMINANCE}

Many of mouse MiHAs were identified at the molecular level in the late 1990s and early 2000s (8). Of these, MiHAs for which the specific $\mathrm{T}$ cell responses have been functionally evaluated are listed in Table 1 (15-25). Although MiHAs are short peptides processed from various proteins, the molecular functions of the native proteins are in general irrelevant to their ability to generate allo-responses. Prototypic MiHA-specific allo-responses emanate from sequence variation within their MHC-presented peptides. The MiHA H60 differs in two respects. First, the native H60 protein serves as a ligand for the NK cell receptor NKG2D $(26,27)$. However, this function is unrelated to the role of H60 as a MiHA (H60 family proteins are introduced in Box 1). More importantly, H60 differs in that its allogenicity is based on its presence or absence of the transcripts $\left(\mathrm{H}_{60} \mathrm{C}\right.$ or $\mathrm{H}^{\mathrm{C}} \mathrm{O}^{\text {null }}$ allele; ${ }^{\mathrm{C}}$ represents allelic variant $\mathrm{C}$, and ${ }^{\text {null }}$ represents alleles with no transcripts) (15). Thus, T cells developed in C57BL/6 (B6; H-2 ${ }^{\mathrm{b}}$ ) mice, which have the $H 60^{\text {null }}$ allele and, thereby, do not express H60, become activated when they encounter the completely foreign $\mathrm{H}-2 \mathrm{~K}^{\mathrm{b}}$-LTFNYRNL peptide $(\mathrm{H} 60 \mathrm{p})$ processed from the protein produced by mouse strains carrying the $H 60^{\mathrm{C}}$ allele, such as BALB and 129.
In a $\mathrm{B} 6$ vs. BALB.B pair, a representative example of $\mathrm{MHC}$ $\left(\mathrm{H} 2^{\mathrm{b}}\right)$-matched allogeneic donor and recipient mouse strains, MiHA number has been estimated up to 88 (29). However, the immunodominance phenomenon focuses the immune responses to fewer antigens, thus simplifying the complexity of the alloresponse. Four MiHAs (H60, H4, H28, and H7) account for great majority of the B6 CD8 T cell responses to allogeneic BALB.B cells (30). But $\mathrm{H} 60$ stands out in that it accounts for more than $30 \%$ of the B6 anti-BALB.B allo-response (Table 1). H60-specific CD8 $\mathrm{T}$ cells expand up to $12 \%$ of the CD8 T cells in the blood of B6 mice once immunized with BALB.B splenocytes [this is termed B6 anti-BALB.B host-versus-graft (HVG) response] and compete effectively with CD8 T cells for the allo-MHC $\left(\mathrm{H}-2^{\mathrm{d}}\right)$ proteins during the $\mathrm{B} 6$ anti-haploidentical $\mathrm{CB} 6 \mathrm{~F} 1 \mathrm{HVG}$ response $(30,31)$. H60 immunogenicity is even more intensified in GVHD. The frequency of the H60-specific CD8 T cells surges up to 25\% of CD8 T cells in peripheral blood and target organs of BALB.B GVHD hosts (7). H60-specific CD8 T cells also prevail in other $\mathrm{H} 2^{\mathrm{b}}$-matched GVHD pairs, such as B6 BMT to A.BY, LP/J, and 129 strains. This unusual level of immunodominance endows the value of $\mathrm{H} 60$ as a model MiHA to manipulate GVH and GVL responses, with growing evidence favoring the uniqueness of $\mathrm{H} 60$ as a GVL target, and is discussed subsequently.

\section{HOW AND WHEN IS H60 IMMUNODOMINANT?}

\section{Hematopoietic Cell-Restricted Expression}

Most known MiHAs exhibit ubiquitous expression patterns. However, H60 is only expressed by hematopoietic lineage cells in mouse strains carrying the $H 60 a^{\mathrm{C}}$ allele $(15,27)$. H60a transcripts are detected in lymphoid organs including the thymus and spleen, but not in the kidney, brain, and intestine of BALB/c mice $(28,32)$. Although one report claimed that $H 60$ a transcripts were found at appreciable levels in some non-hematopoietic tissues such as cardiac and skeletal muscles and skin (28), its expression in non-hematopoieic parenchymal cells has not been validated in allogeneic solid tissue (skin or heart) transplantation models (as will be described below), and could not be confirmed in our laboratory.

In general, $\mathrm{H} 60$-specific $\mathrm{CD} 8 \mathrm{~T}$ cells undergo robust expansion, attaining peaks of $10-15 \%$ of blood CD8 T cells, when B6 mice are immunized with splenocytes from H60 congenic mice (B6.CBy-H60a ; Con-H60 hereafter) (33-35). However, when tail skin from the Con-H60 strain is transplanted onto B6 mice (Con-H60 $\rightarrow$ B6), minimal specific T cell expansion is observed (to an average peak of 3\%) (36). Similarly, Con-H60 $\rightarrow$ B6 skin or heart transplantation is associated with minimal skin graft rejection or coronary artery vascular disease (37). This contrasts greatly with the serious complications (almost $100 \%)$ found after skin or heart transplantation when the H60mismatched donor is the $\mathrm{H} 60$ transgenic mouse line, C57BL/6 Tg (ACTB-H60a*) in which H60 is ubiquitously expressed under the control of the actin-promoter (termed Act-H60 $\mathrm{Tg}$, hereafter) $(37,38)$. Similarly high rates of complications are observed when the solid tissue transplantations feature 
TABLE 1 | Mouse minor histocompatibility antigens.

\begin{tabular}{|c|c|c|c|c|c|c|}
\hline Name & Distribution & $\operatorname{MHC}\left(\mathrm{H}^{\mathrm{b}}\right)^{*}$ & $\begin{array}{l}\text { C57BL/6 (allele/or X) } \\
\text { sequence }\end{array}$ & $\begin{array}{l}\text { BALB.B (allele/or Y) } \\
\text { sequence }\end{array}$ & $\begin{array}{c}\text { Proportions in B6 } \\
\text { anti-BALB.B MLC (30) }\end{array}$ & References \\
\hline H60 (H60a) & Hematopoietic & $\mathrm{K}^{\mathrm{b}}$ & (b) Null & (c) LTFNYRNL & $29.1-36.3 \%$ & $(15)$ \\
\hline $\mathrm{H} 4$ (Emp3) & Broad & $\mathrm{K}^{\mathrm{b}}$ & (a) SGTVYIHL & (b) SGIVYIHL & $6.5-26 \%$ & (16) \\
\hline H28 (IFi44I) & Interferon-induced & $\mathrm{K}^{\mathrm{b}}$ & & (b) ILENFPRL & $6-24.3 \%$ & $(17)$ \\
\hline $\mathrm{H} 7(\mathrm{H} 7)$ & Broad & $D^{b}$ & (a) KAPDNRETL & (b) KAPDNRDTL & $5-8 \%$ & (18) \\
\hline Н3а (Zfp106) & Broad & $\mathrm{D}^{\mathrm{b}}$ & (a) ASPㅌNSTVL & (a) ASPㅌNSTVL & & (19) \\
\hline H13 (H13) & Broad & $\mathrm{D}^{\mathrm{b}}$ & (a) SSWVGWWYL & (b) SSVIGWWYL & $1-4 \%$ & (20) \\
\hline HY-Uty & Broad & $D^{b}$ & $(X: U t x)$ WMHHTVDLL & (Y) WMHHNMDLI & $2-2.5 \%$ & $(21)$ \\
\hline HY-Dby & Broad & $A^{b}$ & $(X: D b x)$ SSSFSSSRASSSRSG & (Y) NAGFNSNRANSSRSS & & $(22)$ \\
\hline
\end{tabular}

Underline, amino acid variation between strains. *Superscript b indicates b haplotype of $\mathrm{H} 2$.

BOX 1 | The native function of $\mathrm{H} 60$.

In terms of molecular function, the native $\mathrm{H} 60$ protein serves as a ligand for the NK cell receptor NKG2D $(26,27)$. After paralog genes (H6Ob and H60c) encoding additional NKG2D ligands were identified (28), the original $H 60$ was renamed $\mathrm{H} 60 \mathrm{a}$. However, $\mathrm{H} 6 \mathrm{Ob}$ and $\mathrm{H60}$ c encode proteins exhibiting amino acid variations at multiple sites including the H60p sequence, LTFNㅌRㅡㄴ and LTVKYRTL, respectively, and were found to be transcribed in both the B6 and BALB strains (28). Thus, the MiHA H6O (simplified to $\mathrm{H} 60$, hereafter) refers to only the $\mathrm{H} 60 \mathrm{a}$-encoded protein that induces the potent $\mathrm{T}$ cell allo-response in mouse strains with the H60anull allele (eg., B6).

mismatch of MiHA H4, a widely expressed MiHA, using the $\mathrm{H} 4$ congenic strain (B10.129- $\mathrm{H} 4^{\mathrm{b}}$; Con-H4) as the donor (37). Collectively, these findings indicate that parenchymal cells do not naturally express H60; expression is restricted to hematopoietic cells and the H60-specific response is weak after solid tissue transplantations. In support of this, BALB.B $\rightarrow$ B6 cardiac engraftment and skin transplantation, neither of which features primary vascularization, $\mathrm{H} 60$ is subordinated to $\mathrm{H} 4$ $(36,39)$. However, when the BALB $\rightarrow$ B6 heart transplantation involves a primary vascularization procedure, so that the BALB.B hematopoietic cells become more exposed to the B6 immune cells, H60 regains its dominance over $\mathrm{H} 4(\mathrm{H} 60>\mathrm{H} 4)$, as after BALB.B spleen cell immunization (30, 39). Similarly, H60 immunodominance is exaggerated during B6 anti-BALB.B GVH responses (7), when homeostatically proliferating B6 T cells are exposed to a large number of H60-positive host leukocytes. Thus, immunodominance of $\mathrm{H} 60$ is flexible and depends on the type of graft. H60 dominance is intensified by the abundance of H60-expressing allogeneic hematopoieic cells, due to its hematopoietic cell-restricted distribution (Figure 1).

\section{Contribution From High Precursor Frequency in the Naïve T Cell Pool}

Various factors affect antigen immunodominance and the immune hierarchy. Affinity for the MHC and the numbers of peptide/MHC complexes are crucial factors influencing immunodominance (40-42). However, the binding affinity of

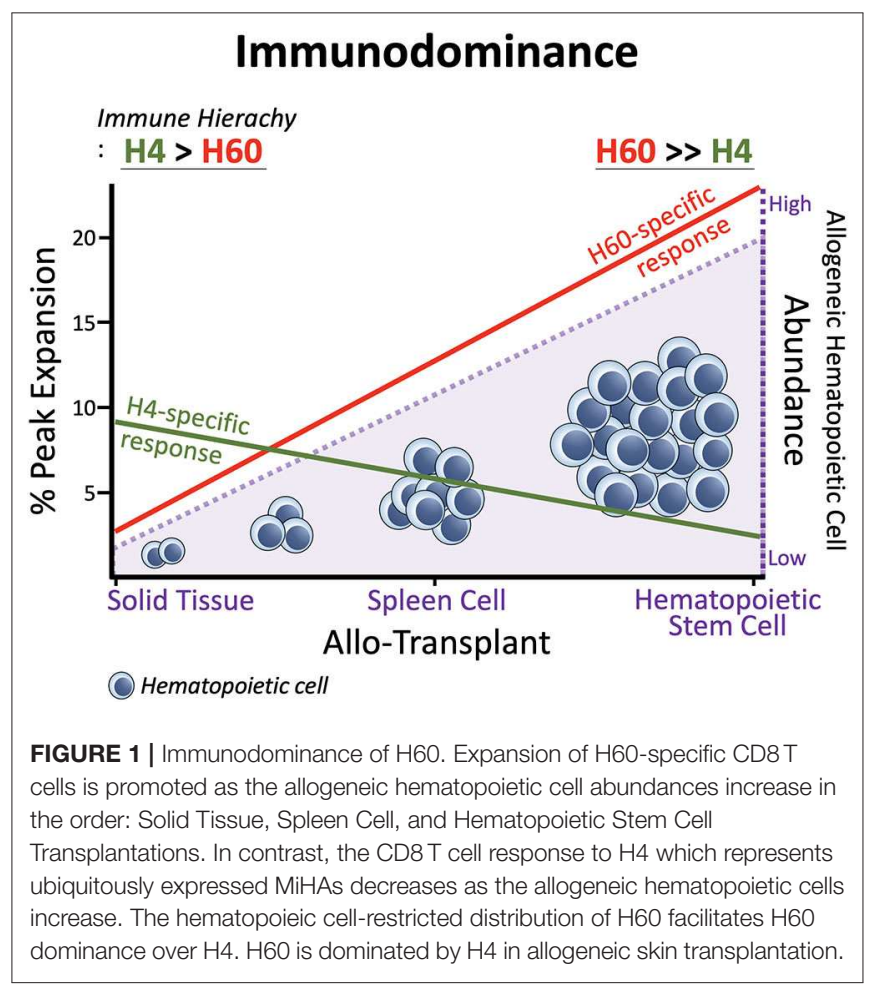

the cognate H60p LTFNYRNL to $\mathrm{H}-2 \mathrm{~K}^{\mathrm{b}}$ is 3 -10-fold lower than that of the Ova $257-264$ SIINFEKL peptide, but is similar to that of the SGIVYIHL H4 ${ }^{\mathrm{b}} \mathrm{CD} 8$ epitope $(\mathrm{Kd}=0.8 \pm$ $0.05 \mathrm{nM}$ ), and empirical estimates of natural LTFNYRNL/H$2 \mathrm{~K}^{\mathrm{b}}$ complexes (5-15 copies per cell) are not exceptionally high $(15,43)$. Thus, affinity and ligand density do not readily explain the unusually high immunodominance; $\mathrm{H} 60$-specific $\mathrm{T}$ cells expand at significant levels (to attain $7-8 \%$ of the peripheral peak) even in the presence of allo-MHC responses during the B6 anti-BALB/c $\left(\mathrm{H}-2^{\mathrm{d}}\right)$ HVG response, and $\mathrm{H} 60$-targeted $\mathrm{T}$ cell cytotoxicity is detected at levels similar to that of $\mathrm{H}-2^{\mathrm{d}}$ targeted cytotoxicity during the haplo-MHC mismatched B6 anti-CB6F1 HVG response (31). H60 immunodominance is reproduced after immunization of $\mathrm{B} 6$ mice with the synthetic 
H60 peptide; naïve protein expression is not involved (31). Rather, precursor cells are significantly frequent in the naïve CD8 T cell pool. The precursor frequencies (ca. 1/24,000$1 / 11,000$ cells) are significantly higher than those of cells recognizing the $\mathrm{H} 13$ and $\mathrm{HY}$ subdominant MiHAs (such cells are in fact undetectable), and comparable to the level of cells reactive to a viral epitope VSV peptide (RGYVYQGL; ca. $1 / 49,000-1 / 18,000$ cells) $(31,44)$. Additionally, the precursor TCR repertoire is diverse as revealed the high shannon entropy (average 5.8) and simpson index (0.99) of rearranged TCR $\beta$ s sequences (45). Consequently, CD8 T cells with a wide spectrum of TCRs, thus almost all TCRV $\beta$ s and the various CDR3s of each TCRV $\beta$, are expanded in B6 mice immunized with spleen cells from Con-H60 mice (46). These features may explain why H60 is so immunogenic. However, because boosting the frequency of subdominant $\mathrm{H} 13$-reactive $\mathrm{T}$ cells via pre-immunization does not attenuate the dominance of H60 (30), not only the frequency and TCR diversity, but also the TCR avidity for $\mathrm{H} 60 \mathrm{p} / \mathrm{H}$ $2 \mathrm{~K}^{\mathrm{b}}$ of the precursors which are generated through selection processes in the $\mathrm{B} 6\left(\mathrm{H} 60^{\text {null }}\right)$ thymic environment likely play roles in establishing the immunodominance of $\mathrm{H} 60$ in the $\mathrm{B} 6 \mathrm{~T}$ cell response.

\section{DOES HEMATOPOIETIC CELL-RESTRICTED DISTRIBUTION AFFECT THYMIC SELECTION OF T CELLS SPECIFIC FOR H60?}

As described above, the immunodominant $\mathrm{H} 60$ serves as useful model antigen when studying anti-MiHA allogeneic $\mathrm{T}$ cell response in MHC-matched allo-HSCT settings. Anti-H60 donor $\mathrm{T}$ cell responses can occur at two different levels. Mature donor $\mathrm{T}$ cells contained in the graft inoculum recognize host $\mathrm{H} 60$ and induce the GVL effect and GVHD. Also, donor-derived naïve $\mathrm{T}$ cells newly developed in the recipient thymus may recognize host $\mathrm{H} 60$ to induce the GVL effect and GVHD. Although many studies have focused on acute effects of the former $\mathrm{T}$ cells, de novo generated naive $\mathrm{T}$ cells also can contribute to both the GVL effect and GVHD. Thus, it is important to understand thymic development of H60-specific naïve T cells. Below, we will describe natural thymic selection of $\mathrm{H} 60$-specific $\mathrm{T}$ cells and under allo-HSCT settings.

\section{Incomplete Thymic Negative Selection of T Cells Specific for Self-Hematopoietic Cell-Restricted Antigens}

It is well-established that $\mathrm{T}$ cells with specificity for ubiquitously expressed self-antigens are deleted in the thymus, preventing $\mathrm{T}$ cell-mediated autoimmunity (47). This is true for tissuerestricted antigens (TRAs) that are expressed only in certain peripheral tissues and cells; antigen-specific $\mathrm{T}$ cells for TRAs can be negatively selected due to AIRE-mediated promiscuous expression of certain genes (such as endocrine genes including insulin) by medullary thymic epithelial cells (mTECs) $(48,49)$. However, in recent years, it has become clear that some $\mathrm{T}$ cells escape thymic negative selection. In particular, certain
TRA-specific T cells, especially those with low avidity TCRs, survive negative selection in the thymus and enter the periphery (50-53). Thymic negative selection against hematopoietic cellrestricted antigens (HRAs), especially natural HRAs such as H60, has not been studied in depth. Thymic dendritic cells (DCs) are known to be responsible for negative selection in the thymus $(47,54,55)$. They have great capacity to delete thymocytes with high affinity/avidity TCRs for self-expressed antigens (direct presentation) and also those expressed by mTECs (cross-presentation) $(56,57)$. The conventional view has thus been that thymic deletion of $\mathrm{T}$ cells specific for HRA would be strict because of its thymic DC expression. However, our recent study using the natural antigen $\mathrm{H} 60$ as self- and allo-HRA revealed that some HRA-specific T cells survive thymic negative selection (45).

Our initial findings came from experiments using TCR-Tg mice of the $\mathrm{B} 6\left(\mathrm{H} 0^{\text {null }}\right)$ background strain, termed J15 mice, in which all $\mathrm{T}$ cells express TCRs originated from a high avidity anti-H60 clone (58). The J15 TCR has high specificity for H60, in that J15 T cells are strictly deleted in the thymus of Act-H60 Tg mice, but not in the thymus of $\mathrm{Tg}$ mice where a signal amino acid variant of $\mathrm{H} 60$ termed $\mathrm{H} 60 \mathrm{H}$ (LTFHYRNL) is expressed under the control of the actin promoter (Act-H60H) $(59,60)$. Despite the high specificity and avidity, J15 T cells are incompletely deleted in the Con-H60 thymus even though the thymic DCs express H60. CD8 single positive (SP) thymocytes and splenic $\mathrm{T}$ cells were generated after crossing J15 and Con-H60 mice, although the numbers were 3-7-fold less and tetramer staining intensity was about 7-fold lower than those of B6 mice. Thus, J15 T cells expressing low avidity TCRs composed of transgenic TCR $\beta$ and endogenous TCR $\alpha$ s escaped negative selection in the Con-H60 thymus. Even under physiological conditions, H60tetramer-binding polyclonal T cells can be detected among CD8 SP thymocytes and splenocytes of Con-H60 mice, albeit with lower tetramer-staining intensities and in numbers 2-2.5-fold lower than those of $\mathrm{B} 6$ mice. However, tetramer-binding cells are rarely detected in Act-H60 Tg mice. Thus, the incomplete deletion of $\mathrm{T}$ cells in the Con-H60 thymus is attributable to the natural hematopoietic cell-restricted expression pattern of H60. This finding allies with a study showing that limiting TRA expression to DCs results in incomplete deletion of thymic CD4 T cells (52).

\section{Incomplete Thymic Negative Selection of T Cells Specific for Allo-HRA H60}

In an H60-single antigen-mismatched allo-HSCT model, $\mathrm{J} 15 \rightarrow$ Con-H60, donor-derived J15 T cells developing de novo are also only partially deleted in the thymus of Con-H60 recipients. Because radiation conditioning induces hematopoietic cell death in the recipient, negative selection may have not occurred. Thus, partial deletion in this setting was somewhat surprising. The mediators of such partial negative selection turned out to be radiation-resistant hematopoietic cells of the Con-H60 recipient: $\mathrm{J} 15 \mathrm{~T}$ cells were positively selected in the $\mathrm{J} 15 \rightarrow \beta 2 \mathrm{~m}^{-/-}$ConH60 BMT, whereas partial deletion was preserved in the $\beta 2 m^{-/-}$J15 $\rightarrow$ Con-H60 BMT. Partial deletion of HRA-specific 
CD8 T cells was also evident when Ova was expressed as an HRA in the recipient of OT-1 BM (OT-1 $\rightarrow$ [Ova Tg $\rightarrow$ B6] $)(45)$.

Therefore, deletion of $\mathrm{T}$ cells specific for HRAs may not be as strict as was conventionally thought. When limited numbers of DCs serve as the cognate thymic APC, the specific T cells are only partially deleted. Even when all thymic DCs are cognate APCs (as in Con-H60 mice), weak antigen-presentation by each APC (515 copies of the antigen-MHC complexes in the case of H60) may prevent strict deletion of the T cells. Thus, the hematopoieticallylimited nature of $\mathrm{H} 60$ presentation allows low avidity $\mathrm{T}$ cells to escape thymic deletion.

\section{A GVL EFFECT MEDIATED BY POST-THYMIC CD8T CELL ESCAPEES SPECIFIC FOR HRA H60}

In some animal models of allo-HSCT, hosts with chronic GVHD exhibit mTEC injuries (61-63). In recipients expressing Ova as a TRA, TRA-specific CD4 T cells are generated de novo because of mTEC damage occurring during the period of acute GVHD. Post-thymic T cells generated without negative selection trigger autoimmune-like disease in the context of a pro-inflammatory milieu (64). Thus, not just the failure of complete negative selection, but also acute GVHD-associated inflammation increases the likelihood that TRA-specific deletion escapees will generate autoimmune-like chronic GVHD.

In the case of H60, CD8 T cell escapees specific for HRA H60 consist of low-avidity $\mathrm{T}$ cells, exhibiting low tetramer-staining intensity. However, their TCR repertoire diversity is comparable to that of the B6 counterparts generated in the absence of negative selection. Escapees generated in B6 $\rightarrow$ Con-H60 BMT recipients are functional, producing IFN- $\gamma$ and proliferating in response to $\mathrm{H} 60$ peptide-stimulation. More importantly, they have potent anti-leukemia effects. $\mathrm{B} 6 \rightarrow$ Con-H60 hosts showed tumor-free survival rates comparable to that of $\mathrm{B} 6 \rightarrow \mathrm{B} 6$ hosts, because tumor cells were eliminated in an antigen-specific

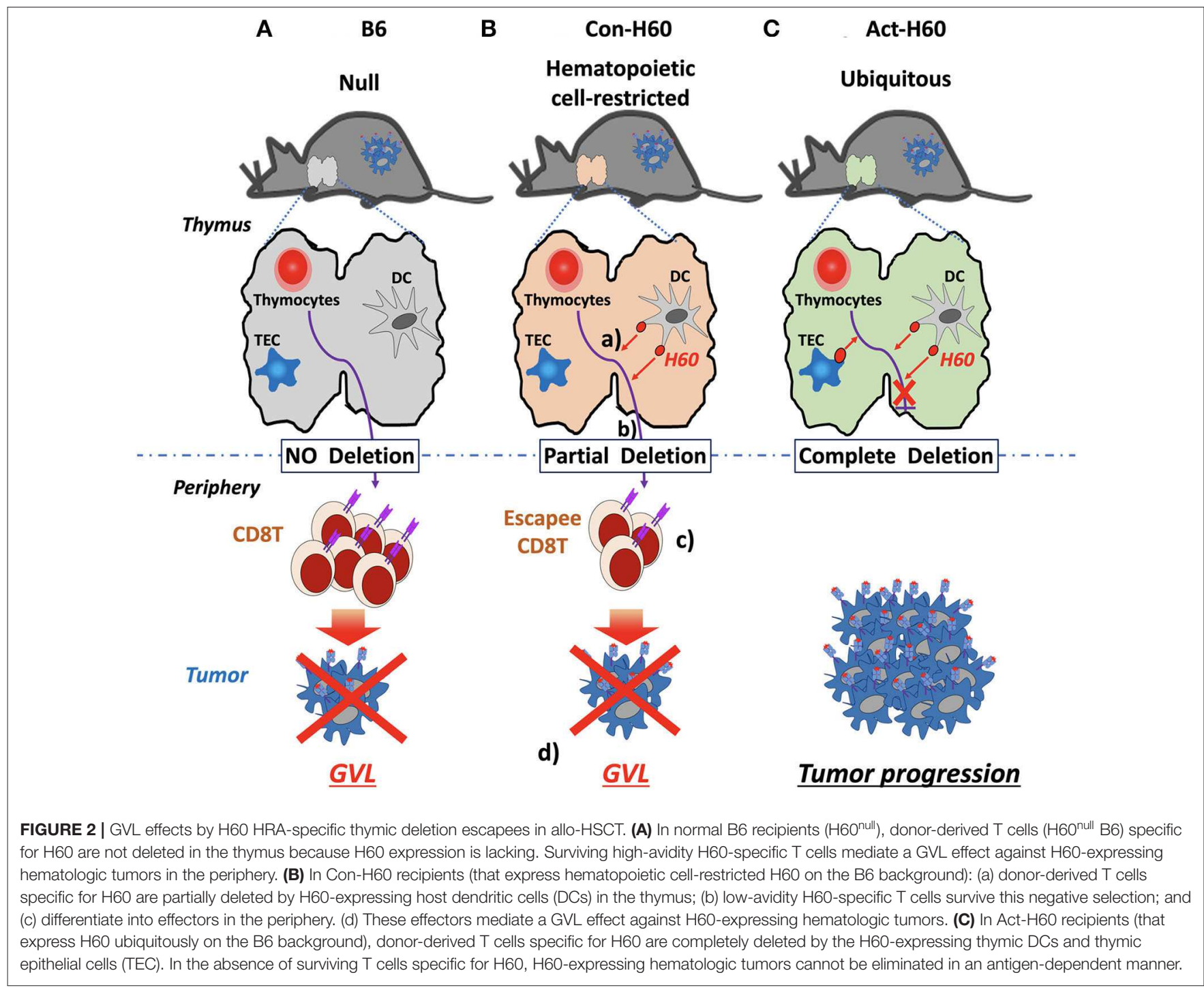


manner (Figures 2A,B). Such GVL effects were not found for $\mathrm{B} 6 \rightarrow$ Act-H60-Tg hosts because of the strict deletion of the H60-specific T cells (Figure 2C). Another critical point is that HRA H60-specific CD8 T cell escapees did not cause GVHDlike symptoms in $\mathrm{B} 6 \rightarrow \mathrm{Con}-\mathrm{H} 60$ hosts. However, when the numbers of escapees are non-physiologically high, as in the $\mathrm{J} 15 \rightarrow$ Con-H60 BMT, GVHD-like symptoms and mortality were observed in some hosts $(<30 \%)$. Other findings have included donor leukocyte chimerism and expansion of H60specific CD8 T cell escapees during the GVL response (45). Such data are clinically relevant as similar phenotypes are observed in leukemic patients showing favorable outcomes after allo-HSCT $(12,65,66)$. Thus, hematopoietic cell-restricted MiHA-specific naïve $\mathrm{T}$ cells can develop in allo-HSCT hosts and contribute to the GVL effect with minimal GVHD, highlighting the potential utility of hematopoietic MiHA-mismatched HSCT in the clinic.

\section{GVL EFFECTS MEDIATED BY DONOR MATURE CD8 T CELLS SPECIFIC FOR HRA H60}

As we mentioned above, during the early phase of alloHSCT, donor-derived mature T cells initiate acute GVH, and GVL responses. Donor-derived mature T cells specific for $\mathrm{H} 60$ expand greatly soon after transplantation, predominating the B6 anti-BALB.B GVH response $(7,67)$. However, depletion of $\mathrm{T}$ cells specific for $\mathrm{H} 60$ (and $\mathrm{H} 4$ ) within the graft prior to transplantation does not alleviate GVHD severity (68), indicating that donor-derived mature $\mathrm{T}$ cells specific for HRA H60 are not critical for inducing acute GVHD. It is thus clear that $\mathrm{T}$ cells responses raised against multiple MiHA-mismatch, rather than the just two MiHA, contribute to GVHD induction, consistent with the fact that an $\mathrm{H} 4$ single mismatch cannot induce acute GVHD (69). However, substantial GVL effects have been observed after transfer of $\mathrm{T}$ cells containing memory cells for $\mathrm{H} 60$ (70, 71). In MHC (H-2 $\left.{ }^{\mathrm{b}}\right)$-matched C3H.SW $\left(\mathrm{H}_{60}{ }^{\text {null }}\right) \rightarrow$ Con-H60 allo-BMT, transfer of CD8 T cells from H60-vaccinated donors, containing 2,600-5,000 H60-tetramer ${ }^{+}$ cells, prolonged the survival of the $\mathrm{H} 60^{+}$tumor-bearing hosts with chronic phase or blast crisis chronic myeloid leukemia (CML) $(70,71)$. The remarkable expansion of the H60-specific $\mathrm{T}$ cells (up to $56 \%$ of splenic CD8 T cells) and effective tumor killing, compared to the naïve $\mathrm{T}$ cell transfer, reflect inclusion in the transplant of central memory cells which can proliferate and differentiate into effector immediately upon antigen-restimulation. In addition to the direct cytotoxic effect, the ability to generate IFN- $\gamma$ producing effectors immediately and in large numbers allows the memory $\mathrm{T}$ cell transfer to exert a powerful GVL effect: IFN- $\gamma$ sensitizes GVL-resistant blast crisis CML and acute myeloid leukemia to T cell-mediated killing (71). Notably, this memory cell transfer strategy does not generate the GVL effects in hosts where H60 is ubiquitously expressed (70). The memory cells induce only mild hepatic GVHD, unlike the typical aggressive GVHD seen in hosts transferred with naïve $\mathrm{T}$ cells. Thus, memory $\mathrm{T}$ cells specific for an HRA may serve as tumor-targeting tools mediating a
GVL effect. CD4 help is required for appropriate generation and expansion of memory CD8 $\mathrm{T}$ cells specific for cellular antigens including $\mathrm{H} 60$ (34, 35). Therefore, the development of strategies that include or supplement CD4 help factors will render amplification of memory $\mathrm{T}$ cells feasible. Collectively, GVL studies using $\mathrm{H} 60$ as a model HRA have validated the use of HRA-mismatched allo-HSCT and HRA-specific memory T cells to maximize GVL effects, while minimizing GVHD, in treatment of hematological malignancies.

\section{CONCLUSION}

We have reviewed the molecular characteristics of H60, a hematopoieic cell-restricted immunodominant MiHA, and the GVL effects of specific T cells. H60 allelism ( $\mathrm{H}_{60 a^{\text {null }}}$ vs. $\left.\mathrm{H60a^{ \textrm {C } }}\right)$ and the hematopoietic cell-restricted distribution explain the mechanisms, such as the frequency, diversity, and avidity of reactive $\mathrm{T}$ cells, which underlie $\mathrm{H} 60$ immunodominance and the GVL effect of H60-specific T cells. Particularly, thymic deletion escapes of T cells with low avidity for HRA H60, and a GVL effect generated by the escapees against H60-positive tumor cells in the periphery have not been evaluated previously. These findings, together with the GVL effect generated by the transfer of memory T cells, emphasize the utility of HRA identification and the use of HRA-mismatched allo-HSCT to treat leukemia and lymphoma.

HRA-mismatched allo-HSCT, and the potential use of human HRAs such as HA-1 (HMHA1; VLH/RDDLLEA restricted by HLA-A*0201) and HA-2 (MYO1G; YIGEVLVSV/M restricted by HLA-A*0201) as targets for lysis of leukemic cells have been evaluated in clinic for years (72-75). The HA-1-mismatched alloHSCT followed by HA-1-negative donor lymphocyte infusions successfully treated a relapse of $\mathrm{HA}-1^{+}$leukemia (12, 76, 77). $\mathrm{T}$ cell clones from patients with GVL in the absence of GVHD consistently did not react with non-hematopoietic cells, whereas those from GVHD patients were skewed to broadly expressed MiHAs (78). TCRs from high avidity HA-1specific clones were used to develop memory $\mathrm{T}$ cells targeting leukemia (79). In this respect, identification of HRAs and their specific $\mathrm{T}$ cell clones is valuable. HRA expression may not be static, being possibly down-regulated by physiological, or pathological signals including IFNs $(80,81)$. However, MiHAs afford advantages compared to highly personalized tumorassociated neo-antigens, in that MiHAs shared by a group of people may allow germ-line based treatments. Moreover, the expression of certain HRAs, such as H60 and HA-1 (82-84), can be ectopically induced during carcinogenesis, extending the potential of HRA-based therapies to solid tumor target. Recently, a library of 39 novel MiHAs (restricted by HLA$\mathrm{A}^{*}$ 02:01 or HLA-B*44:03) expressed on hematological cells has been reported (10). Molecular characterizations of these MiHAs and the reactive $\mathrm{T}$ cells will aid the utilization of HRAs as GVL targets. Our present review will assist in selection of HRAs for clinical applications.

In summary, mouse studies using $\mathrm{H} 60$ as a model HRA have yielded basic knowledge supporting the importance of strong 
immunogenic HRAs, and donor-derived post-thymic T cells and memory $\mathrm{T}$ cells specific for such HRAs for generation of GVL effects. The $\mathrm{H} 60^{+}$tumor targeting by post-thymic $\mathrm{T}$ cell was revealed using a single antigen-mismatched model. This will be extended to multi-antigen-mismatched allo-HSCT models. Also, future mechanistic studies on GVL mediation by H60-specific $\mathrm{T}$ cells will increase our ability to develop strategies that sustain anti-tumor effects while minimizing GVHD or autoimmunelike symptoms.

\section{AUTHOR CONTRIBUTIONS}

EC wrote the manuscript. KC provided critical insight and edited the manuscript. GN provided supportive

\section{REFERENCES}

1. Mackall CL, Fleisher TA, Brown MR, Andrich MP, Chen CC, Feuerstein IM, et al. Age, thymopoiesis, and CD4+ T-lymphocyte regeneration after intensive chemotherapy. $N$ Engl J Med. (1995) 332:143-9. doi: 10.1056/NEJM199501193320303

2. Mackall CL, Gress RE. Pathways of T-cell regeneration in mice and humans: implications for bone marrow transplantation and immunotherapy. Immunol Rev. (1997) 157:61-72. doi: 10.1111/j.1600-065X.1997.tb00974.x

3. Horowitz MM, Gale RP, Sondel PM, Goldman JM, Kersey J, Kolb HJ, et al. Graft-versus-leukemia reactions after bone marrow transplantation. Blood. (1990) 75:555-62. doi: 10.1182/blood.V75.3.555.bloodjournal753555

4. Bleakley M, Riddell SR. Molecules and mechanisms of the graft-versusleukaemia effect. Nat Rev. (2004) 4:371-80. doi: 10.1038/nrc1365

5. Ferrara JL, Deeg HJ. Graft-versus-host disease. N Engl J Med. (1991) 324:66774. doi: 10.1056/NEJM199103073241005

6. Goulmy E, Schipper R, Pool J, Blokland E, Falkenburg F, Vossen J, et al. Mismatches of minor histocompatibility antigens between HLA-identical donors and recipients and the development of graft-versus-host disease after bone marrow transplantation. New Engl J Med. (1996) 334:2815. doi: 10.1056/NEJM199602013340501

7. Choi EY, Christianson GJ, Yoshimura Y, Jung N, Sproule TJ, Malarkannan $\mathrm{S}$, et al. Real-time T-cell profiling identifies $\mathrm{H} 60$ as a major minor histocompatibility antigen in murine graft-versus-host disease. Blood. (2002) 100:4259-64. doi: 10.1182/blood-2002-05-1299

8. Roopenian D, Choi EY, Brown A. The immunogenomics of minor histocompatibility antigens. Immunol Rev. (2002) 190:8694. doi: 10.1034/j.1600-065X.2002.19007.x

9. Kowalewski DJ, Schuster H, Backert L, Berlin C, Kahn S, Kanz L, et al. HLA ligandome analysis identifies the underlying specificities of spontaneous antileukemia immune responses in chronic lymphocytic leukemia (CLL). Proc Natl Acad Sci USA. (2015) 112:E166-75. doi: 10.1073/pnas.1416389112

10. Granados DP, Rodenbrock A, Laverdure JP, Cote C, Caron-Lizotte O, Carli C, et al. Proteogenomic-based discovery of minor histocompatibility antigens with suitable features for immunotherapy of hematologic cancers. Leukemia. (2016) 30:1344-54. doi: 10.1038/leu.2016.22

11. Hombrink P, Hassan C, Kester MG, Jahn L, Pont MJ, de Ru AH, et al. Identification of biological relevant minor histocompatibility antigens within the B-lymphocyte-Derived HLA-ligandome using a reverse immunology approach. Clin Cancer Res. (2015) 21:2177-86. doi: 10.1158/1078-0432.CCR-14-2188

12. Marijt WA, Heemskerk MH, Kloosterboer FM, Goulmy E, Kester MG, van der Hoorn MA, et al. Hematopoiesis-restricted minor histocompatibility antigens HA-1- or HA-2-specific T cells can induce complete remissions of relapsed leukemia. Proc Natl Acad Sci USA. (2003) 100:2742-7. doi: 10.1073/pnas.0530192100 experimental data. GN, WK, and MC designed the figures.

\section{FUNDING}

This work was supported by grants from the National Research Foundation funded by the Ministry of Science and ICT (Basic Research Laboratory 2017R1A4A1015745; Basic Research Program 2019R1A2C3004336) and Seoul National University Hospital, Republic of Korea.

\section{ACKNOWLEDGMENTS}

We thank Young Keul Jeon for his technical help and Dr. Derry Roopenian for his editorial suggestion.
13. Spierings E, Wieles B, Goulmy E. Minor histocompatibility antigens-big in tumour therapy. Trends Immunol. (2004) 25:56-60. doi: $10.1016 /$ j.it.2003.12.002

14. Goulmy E. Minor histocompatibility antigens: allo target molecules for tumor-specific immunotherapy. Cancer J. (2004) 10:1-7. doi: 10.1097/00130404-200401000-00001

15. Malarkannan S, Shih PP, Eden PA, Horng T, Zuberi AR, Christianson G, et al. The molecular and functional characterization of a dominant minor $\mathrm{H}$ antigen, H60. J Immunol. (1998) 161:3501-9.

16. Luedtke B, Pooler LM, Choi EY, Tranchita AM, Reinbold CJ, Brown $\mathrm{AC}$, et al. A single nucleotide polymorphism in the Emp3 gene defines the H4 minor histocompatibility antigen. Immunogenetics. (2003) 55:28495. doi: 10.1007/s00251-003-0581-x

17. Malarkannan S, Horng T, Eden P, Gonzalez F, Shih P, Brouwenstijn $\mathrm{N}$, et al. Differences that matter: major cytotoxic $\mathrm{T}$ cellstimulating minor histocompatibility antigens. Immunity. (2000) 13:333-44. doi: 10.1016/S1074-7613(00)00033-9

18. Reinbold CJ, Malarkannan S. Recognition of allo-peptide is governed by novel anchor imposition and limited variations in TCR contact residues. Mol Immunol. (2008) 45:1318-26. doi: 10.1016/j.molimm.2007.09.017

19. Zuberi AR, Christianson GJ, Mendoza LM, Shastri N, Roopenian DC. Positional cloning and molecular characterization of an immunodominant cytotoxic determinant of the mouse $\mathrm{H} 3$ minor histocompatibility complex. Immunity. (1998) 9:687-98. doi: 10.1016/S1074-7613(00)80666-4

20. Ostrov DA, Roden MM, Shi W, Palmieri E, Christianson GJ, Mendoza L, et al. How H13 histocompatibility peptides differing by a single methyl group and lacking conventional MHC binding anchor motifs determine self-nonself discrimination. J Immunol. (2002) 168:283-9. doi: 10.4049/jimmunol.168.1.283

21. Greenfield A, Scott D, Pennisi D, Ehrmann I, Ellis P, Cooper L, et al. An HYDb epitope is encoded by a novel mouse Y chromosome gene. Nat Genet. (1996) 14:474-8. doi: 10.1038/ng1296-474

22. Scott D, Addey C, Ellis P, James E, Mitchell MJ, Saut N, et al. Dendritic cells permit identification of genes encoding MHC class IIrestricted epitopes of transplantation antigens. Immunity. (2000) 12:71120. doi: 10.1016/S1074-7613(00)80221-6

23. McBride K, Baron C, Picard S, Martin S, Boismenu D, Bell A, et al. The model B6(dom1) minor histocompatibility antigen is encoded by a mouse homolog of the yeast STT3 gene. Immunogenetics. (2002) 54:5629. doi: 10.1007/s00251-002-0502-4

24. Mendoza LM, Paz P, Zuberi A, Christianson G, Roopenian D, Shastri N. Minors held by majors: the H13 minor histocompatibility locus defined as a peptide/MHC class I complex. Immunity. (1997) 7:46172. doi: 10.1016/S1074-7613(00)80368-4

25. Eden PA, Christianson GJ, Fontaine P, Wettstein PJ, Perreault C, Roopenian DC. Biochemical and immunogenetic analysis of an immunodominant 
peptide (B6dom1) encoded by the classical $\mathrm{H} 7$ minor histocompatibility locus. J Immunol. (1999) 162:4502-10.

26. Cerwenka A, O'Callaghan CA, Hamerman JA, Yadav R, Ajayi W, Roopenian DC, et al. Cutting edge: the minor histocompatibility antigen $\mathrm{H} 60$ peptide interacts with both H-2Kb and NKG2D. J Immunol. (2002) 168:31314. doi: 10.4049/jimmunol.168.7.3131

27. Diefenbach A, Jamieson AM, Liu SD, Shastri N, Raulet DH. Ligands for the murine NKG2D receptor: expression by tumor cells and activation of NK cells and macrophages. Nat Immunol. (2000) 1:119-26. doi: 10.1038/77793

28. Takada A, Yoshida S, Kajikawa M, Miyatake Y, Tomaru U, Sakai M, et al. Two novel NKG2D ligands of the mouse H60 family with differential expression patterns and binding affinities to NKG2D. J Immunol. (2008) 180:167885. doi: 10.4049/jimmunol.180.3.1678

29. Graff RJ, Brown DH. Estimates of histocompatibility differences between inbred mouse strains. Immunogenetics. (1978) 7:36773. doi: $10.1007 / \mathrm{BF} 01844026$

30. Choi EY, Yoshimura Y, Christianson GJ, Sproule TJ, Malarkannan $\mathrm{S}$, Shastri $\mathrm{N}$, et al. Quantitative analysis of the immune response to mouse non-MHC transplantation antigens in vivo: the H60 histocompatibility antigen dominates over all others. J Immunol. (2001) 166:4370-9. doi: 10.4049/jimmunol.166.7.4370

31. Choi EY, Christianson GJ, Yoshimura Y, Sproule TJ, Jung N, Joyce S, et al. Immunodominance of $\mathrm{H} 60$ is caused by an abnormally high precursor $\mathrm{T}$ cell pool directed against its unique minor histocompatibility antigen peptide. Immunity. (2002) 17:593-603. doi: 10.1016/S1074-7613(02)00428-4

32. Cerwenka A, Bakker AB, McClanahan T, Wagner J, Wu J, Phillips $\mathrm{JH}$, et al. Retinoic acid early inducible genes define a ligand family for the activating NKG2D receptor in mice. Immunity. (2000) 12:7217. doi: 10.1016/S1074-7613(00)80222-8

33. Jung KM, Choi EY. Role for CD40 and CD40L expression in generating CD8 T cell response to minor histocompatibility antigen, H60. Immunenetwork. (2007) 7:6. doi: 10.4110/in.2007.7.4.173

34. Ryu SJ, Jung KM, Yoo HS, Kim TW, Kim S, Chang J, et al. Cognate CD4 help is essential for the reactivation and expansion of CD8 memory T cells directed against the hematopoietic cell-specific dominant minor histocompatibility antigen, H60. Blood. (2009) 113:4273-80. doi: 10.1182/blood-2008-09-1 81263

35. Kim J, Ryu SJ, Oh K, Ju JM, Jeon JY, Nam G, et al. Memory programming in CD8 $(+)$ T-cell differentiation is intrinsic and is not determined by CD4 help. Nat Commun. (2015) 6:7994. doi: 10.1038/ncomms8994

36. Yoo KI, Jeon JY, Ryu SJ, Nam G, Youn H, Choi EY. Subdominant H60 antigenspecific CD8 T-cell response precedes dominant $\mathrm{H} 4$ antigen-specific response during the initial phase of allogenic skin graft rejection. Exp Mol Med. (2015) 47:e140. doi: 10.1038/emm.2014.107

37. Russell PS, Chase CM, Madsen JC, Hirohashi T, Cornell LD, Sproule $\mathrm{TJ}$, et al. Coronary artery disease from isolated non- $\mathrm{H} 2$-determined incompatibilities in transplanted mouse hearts. Transplantation. (2011) 91:847-52. doi: 10.1097/TP.0b013e3182122f82

38. Wang X, Li H, Matte-Martone C, Cui W, Li N, Tan HS, et al. Mechanisms of antigen presentation to $\mathrm{T}$ cells in murine graft-versus-host disease: cross-presentation and the appearance of cross-presentation. Blood. (2011) 118:6426-37. doi: 10.1182/blood-2011-06-358747

39. Kwun J, Malarkannan S, Burlingham WJ, Knechtle SJ. Primary vascularization of the graft determines the immunodominance of murine minor $\mathrm{H}$ antigens during organ transplantation. I Immunol. (2011) 187:39974006. doi: 10.4049/jimmunol.1003918

40. Perreault C, Roy DC, Fortin C. Immunodominant minor histocompatibility antigens: the major ones. Immunol Today. (1998) 19:69-74. doi: 10.1016/S0167-5699(97)01185-7

41. Grufman P, Wolpert EZ, Sandberg JK, Karre K. T cell competition for the antigen-presenting cell as a model for immunodominance in the cytotoxic $\mathrm{T}$ lymphocyte response against minor histocompatibility antigens. Eur $J$ Immunol. (1999) 29:2197-204.

42. Kedl RM, Rees WA, Hildeman DA, Schaefer B, Mitchell T, Kappler J, et al. $\mathrm{T}$ cells compete for access to antigen-bearing antigen-presenting cells. J Exp Med. (2000) 192:1105-13. doi: 10.1084/jem.192.8.1105

43. Yoshimura Y, Yadav R, Christianson GJ, Ajayi WU, Roopenian $\mathrm{DC}$, Joyce S. Duration of alloantigen presentation and avidity of $\mathrm{T}$ cell antigen recognition correlate with immunodominance of CTL response to minor histocompatibility antigens. J Immunol. (2004) 172:6666-74. doi: 10.4049/jimmunol.172.11.6666

44. Van Bleek GM, Nathenson SG. Isolation of an endogenously processed immunodominant viral peptide from the class I $\mathrm{H}-2 \mathrm{~Kb}$ molecule. Nature. (1990) 348:213-6. doi: 10.1038/348213a0

45. Ju JM, Jung MH, Nam G, Kim W, Oh S, Kim HD, et al. Escape from thymic deletion and anti-leukemic effects of $\mathrm{T}$ cells specific for hematopoietic cell-restricted antigen. Nat Commun. (2018) 9:225. doi: 10.1038/s41467-017-02665-z

46. Choi JH, Ryu SJ, Jung KM, Kim S, Chang J, Kim TW, et al. TCR diversity of H60-specific CD8 T cells during the response evolution and influence of CD4 help. Transplantation. (2009) 87:1609-16. doi: 10.1097/TP.0b013e3181a52dc4

47. Klein L, Hinterberger M, Wirnsberger G, Kyewski B. Antigen presentation in the thymus for positive selection and central tolerance induction. Nat Rev Immunol. (2009) 9:833-44. doi: 10.1038/nri2669

48. Derbinski J, Schulte A, Kyewski B, Klein L. Promiscuous gene expression in medullary thymic epithelial cells mirrors the peripheral self. Nat Immunol. (2001) 2:1032-9. doi: 10.1038/ni723

49. Koble C, Kyewski B. The thymic medulla: a unique microenvironment for intercellular self-antigen transfer. J Exp Med. (2009) 206:150513. doi: $10.1084 /$ jem. 20082449

50. Enouz S, Carrié L, Merkler D, Bevan MJ, Zehn D. Autoreactive T cells bypass negative selection and respond to self-antigen stimulation during infection. $J$ Exp Med. (2012) 209:1769-79. doi: 10.1084/jem.20120905

51. Zehn D, Bevan MJ. T cells with low avidity for a tissue-restricted antigen routinely evade central and peripheral tolerance and cause autoimmunity. Immunity. (2006) 25:261-70. doi: 10.1016/j.immuni.2006.06.009

52. Malhotra D, Linehan JL, Dileepan T, Lee YJ, Purtha WE, Lu JV, et al. Tolerance is established in polyclonal CD4(+) T cells by distinct mechanisms, according to self-peptide expression patterns. Nat Immunol. (2016) 17:18795. doi: $10.1038 /$ ni. 3327

53. Yu W, Jiang N, Ebert PJ, Kidd BA, Muller S, Lund PJ, et al. Clonal deletion prunes but does not eliminate self-specific alphabeta $\mathrm{CD} 8(+) \mathrm{T}$ lymphocytes. Immunity. (2015) 42:929-41. doi: 10.1016/j.immuni.2015.05.001

54. McCaughtry TM, Hogquist KA. Central tolerance: what have we learned from mice? Semin Immunopathol. (2008) 30:399409. doi: 10.1007/s00281-008-0137-0

55. Melichar HJ, Ross JO, Herzmark P, Hogquist KA, Robey EA. Distinct temporal patterns of T cell receptor signaling during positive versus negative selection in situ. Sci Signal. (2013) 6:ra92. doi: 10.1126/scisignal.2004400

56. Klein L, Kyewski B, Allen PM, Hogquist KA. Positive and negative selection of the T cell repertoire: what thymocytes see (and don't see). Nat Rev Immunol. (2014) 14:377-91. doi: 10.1038/nri3667

57. Hubert FX, Kinkel SA, Davey GM, Phipson B, Mueller SN, Liston $A$, et al. Aire regulates the transfer of antigen from mTECs to dendritic cells for induction of thymic tolerance. Blood. (2011) 118:2462-72. doi: 10.1182/blood-2010-06-286393

58. Jeon JY, Jung KM, Chang J, Choi EY. Characterization of CTL clones specific for single antigen, $\mathrm{H} 60$ minor histocompatibility antigen. Immune Netw. (2011) 11:100-6. doi: 10.4110/in.2011.11.2.100

59. Ryu SJ, Jeon JY, Chang J, Sproule TJ, Roopenian DC, Choi EY. A single-aminoacid variant of the $\mathrm{H} 60 \mathrm{CD} 8$ epitope generates specific immunity with diverse TCR recruitment. Mol Cells. (2012) 33:393-9. doi: 10.1007/s10059-012-0008-3

60. Ju JM, Kim MB, Ryu SJ, Kim JY, Chang J, Choi EY. Selection of thymocytes expressing transgenic TCR specific for a minor histocompatibility antigen, H60. Immune Netw. (2015) 15:222-31. doi: 10.4110/in.2015.15.5.222

61. Wu T, Young JS, Johnston H, Ni X, Deng R, Racine J, et al. Thymic damage, impaired negative selection, and development of chronic graft-versus-host disease caused by donor CD4+ and CD8+ T cells. J Immunol. (2013) 191:48899. doi: 10.4049/jimmunol.1300657

62. Muller AMS, Min D, Wernig G, Levy RB, Perez VL, Herretes S, et al. Modeling chronic graft-versus-host disease in MHC-matched mouse strains: genetics, graft composition, and tissue targets. Biol Blood Marrow Transplant. (2019) 25:2338-49. doi: 10.1016/j.bbmt.2019. 08.001

63. Dertschnig S, Hauri-Hohl MM, Vollmer M, Hollander GA, Krenger W. Impaired thymic expression of tissue-restricted antigens licenses the de novo 
generation of autoreactive CD4+ T cells in acute GVHD. Blood. (2015) 125:2720-3. doi: 10.1182/blood-2014-08-597245

64. Teshima T, Reddy P, Liu C, Williams D, Cooke KR, Ferrara JL. Impaired thymic negative selection causes autoimmune graft-versus-host disease. Blood. (2003) 102:429-35. doi: 10.1182/blood-2003-01-0266

65. Kroger N, Bacher U, Bader P, Bottcher S, Borowitz MJ, Dreger P, et al. NCI first international workshop on the biology, prevention, and treatment of relapse after allogeneic hematopoietic stem cell transplantation: report from the committee on disease-specific methods and strategies for monitoring relapse following allogeneic stem cell transplantation. Part I: methods, acute leukemias, and myelodysplastic syndromes. Biol Blood Marrow Transplant. (2010) 16:1187-211. doi: 10.1016/j.bbmt.2010.06.008

66. van der Torren CR, van Hensbergen Y, Luther S, Aghai Z, Rychnavska ZS, Slot $\mathrm{M}$, et al. Possible role of minor $\mathrm{h}$ antigens in the persistence of donor chimerism after stem cell transplantation; relevance for sustained leukemia remission. PLoS ONE. (2015) 10:e0119595. doi: 10.1371/journal.pone.0119595

67. Song MG, Kang B, Jeon JY, Chang J, Lee S, Min CK, et al. In vivo imaging of differences in early donor cell proliferation in graft-versus-host disease hosts with different pre-conditioning doses. Mol Cells. (2012) 33:7986. doi: 10.1007/s10059-012-2228-y

68. de Witte MA, Toebes M, Song J-Y, Wolkers MC, Schumacher TN. Effective graft depletion of MiHAg T-cell specificities and consequences for graft-versus-host disease. Blood. (2007) 109:3830-8. doi: 10.1182/blood-2006-07-037713

69. Blazar BR, Roopenian DC, Taylor PA, Christianson GJ, PanoskaltsisMortari A, Vallera DA. Lack of GVHD across classical, single minor histocompatibiliTy $(\mathrm{miH})$ locus barriers in mice. Transplantation. (1996) 61:619-24. doi: 10.1097/00007890-199602270-00017

70. Li N, Matte-Martone C, Zheng H, Cui W, Venkatesan S, Tan HS, et al. Memory T cells from minor histocompatibility antigen-vaccinated and virusimmune donors improve GVL and immune reconstitution. Blood. (2011) 118:5965-76. doi: 10.1182/blood-2011-07-367011

71. Matte-Martone C, Liu J, Zhou M, Chikina M, Green DR, Harty JT, et al. Differential requirements for myeloid leukemia IFN- $\gamma$ conditioning determine graft-versus-leukemia resistance and sensitivity. J Clin Invest. (2017) 127:2765-76. doi: 10.1172/JCI85736

72. de Bueger M, Bakker A, Van Rood JJ, Van der Woude F, Goulmy E. Tissue distribution of human minor histocompatibility antigens. ubiquitous versus restricted tissue distribution indicates heterogeneity among human cytotoxic T lymphocyte-defined non-MHC antigens. J Immunol. (1992) 149:1788-94.

73. den Haan JM, Sherman NE, Blokland E, Huczko E, Koning F, Drijfhout JW, et al. Identification of a graft versus host diseaseassociated human minor histocompatibility antigen. Science. (1995) 268:1476-80. doi: 10.1126/science.7539551

74. den Haan JM, Meadows LM, Wang W, Pool J, Blokland E, Bishop TL, et al. The minor histocompatibility antigen HA-1: a diallelic gene with a single amino acid polymorphism. Science. (1998) 279:10547. doi: $10.1126 /$ science.279.5353.1054

75. Wilke M, Dolstra H, Maas F, Pool J, Brouwer R, Falkenburg JH, et al. Quantification of the HA-1 gene product at the RNA level; relevance for immunotherapy of hematological malignancies. Hematol J. (2003) 4:31520. doi: $10.1038 /$ sj.thj.6200318

76. Kircher B, Stevanovic S, Urbanek M, Mitterschiffthaler A, Rammensee HG, Grunewald K, et al. Induction of HA-1-specific cytotoxic T-cell clones parallels the therapeutic effect of donor lymphocyte infusion. Br J Haematol. (2002) 117:935-9. doi: 10.1046/j.1365-2141.2002.03536.x

77. Kloosterboer FM, van Luxemburg-Heijs SA, van Soest RA, Barbui AM, van Egmond HM, Strijbosch MP, et al. Direct cloning of leukemia-reactive $\mathrm{T}$ cells from patients treated with donor lymphocyte infusion shows a relative dominance of hematopoiesis-restricted minor histocompatibility antigen HA-1 and HA-2 specific T cells. Leukemia. (2004) 18:798808. doi: 10.1038/sj.leu.2403297

78. van Bergen CA, van Luxemburg-Heijs SA, de Wreede LC, Eefting M, von dem Borne PA, van Balen P, et al. Selective graft-versus-leukemia depends on magnitude and diversity of the alloreactive T cell response. J Clin Invest. (2017) 127:517-29. doi: 10.1172/JCI86175

79. Dossa RG, Cunningham T, Sommermeyer D, Medina-Rodriguez I, Biernacki MA, Foster K, et al. Development of T-cell immunotherapy for hematopoietic stem cell transplantation recipients at risk of leukemia relapse. Blood. (2018) 131:108-20. doi: 10.1182/blood-2017-07-791608

80. Bui JD, Carayannopoulos LN, Lanier LL, Yokoyama WM, Schreiber RD. IFNdependent down-regulation of the NKG2D ligand H60 on tumors. J Immunol. (2006) 176:905-13. doi: 10.4049/jimmunol.176.2.905

81. Zhang H, Hardamon C, Sagoe B, Ngolab J, Bui JD. Studies of the H60a locus in C57BL/6 and 129/Sv mouse strains identify the H60a 3'UTR as a regulator of H60a expression. Mol Immunol. (2011) 48:53945. doi: 10.1016/j.molimm.2010.10.015

82. Girardi M, Oppenheim DE, Steele CR, Lewis JM, Glusac E, Filler R, et al. Regulation of cutaneous malignancy by gammadelta T cells. Science. (2001) 294:605-9. doi: 10.1126/science.1063916

83. Klein CA, Wilke M, Pool J, Vermeulen C, Blokland E, Burghart E, et al. The hematopoietic system-specific minor histocompatibility antigen HA 1 shows aberrant expression in epithelial cancer cells. J Exp Med. (2002) 196:359-68. doi: 10.1084/jem.20011838

84. Xu P, Ma J, Ma J, Zhang W, Guo S, Jian Z, et al. Multiple protumorigenic functions of the human minor Histocompatibility Antigen1 (HA-1) in melanoma progression. I Dermatol Sci. (2017) 88:21624. doi: 10.1016/j.jdermsci.2017.07.004

Conflict of Interest: The authors declare that the research was conducted in the absence of any commercial or financial relationships that could be construed as a potential conflict of interest.

Copyright (C) 2020 Choi, Choi, Nam, Kim and Chung. This is an open-access article distributed under the terms of the Creative Commons Attribution License (CC BY). The use, distribution or reproduction in other forums is permitted, provided the original author(s) and the copyright owner(s) are credited and that the original publication in this journal is cited, in accordance with accepted academic practice. No use, distribution or reproduction is permitted which does not comply with these terms. 